\title{
Effects of paeonol on intracellular calcium concentration and expression of RUNX3 in LoVo human colon cancer cells
}

\author{
MING LI, SHI-YUN TAN, JUN ZHANG and HONG-XIA YOU \\ Department of Gastroenterology, Renmin Hospital of Wuhan University, Wuhan, Hubei 430060, P.R. China
}

Received November 11, 2012; Accepted March 12, 2013

DOI: $10.3892 / \mathrm{mmr} .2013 .1372$

\begin{abstract}
Paeonol, a major phenolic component of the root bark of Paeonia moutan, is known to exhibit antitumor effects. However, the underlying mechanisms remain unknown. In the present study, the effects of paeonol on cell viability, intracellular calcium concentration and the expression of runt-related transcription factor 3 (RUNX3) were analyzed in LoVo human colon cancer cells. Results revealed that paeonol markedly reduced LoVo cell viability in a time- and dose-dependent manner. Flow cytometry assays demonstrated that paeonol blocked the cell cycle at the $\mathrm{G}_{1}$ to $\mathrm{S}$ transition and significantly induced apoptosis in LoVo cells. Intracellular calcium accumulation occurred following a $48 \mathrm{~h}$ treatment with paeonol. Furthermore, RUNX3 gene expression was increased in paeonol-treated cells. These observations indicate that paeonol possesses antiproliferative properties and apoptosis-inducing activity. One of the antitumor mechanisms of paeonol may be its apoptosis-inducing activity through an increased intracellular calcium concentration and the upregulation of RUNX3 expression. Paeonol may be a promising antitumor agent for colon carcinoma treatment.
\end{abstract}

\section{Introduction}

Cancer is the second leading cause of death in industrialized countries. Colorectal cancer, a malignant tumor of the digestive system, is the second most common cause of cancer-related mortalities (1). Surgical resection remains the main curative treatment. However, with high rates of adjacent tissue invasion, metastasis and recurrence, attempts to improve the outcomes of this disease have incorporated the use of adjuvant chemotherapy. Cisplatin, cyclophosphamide and 5-fluorouracil are chemotherapeutical drugs utilized in cancer treatment. However, the development of drug resistance and severe side effects of standard anticancer drugs necessitates

Correspondence to: Professor Shi-Yun Tan, Department of Gastroenterology, Renmin Hospital of Wuhan University, 238 Jiefang Road, Wuhan, Hubei 430060, P.R. China

E-mail: tanshiyun@medmail.com.cn

Key words: paeonol, apoptosis, $\mathrm{Ca}^{2+}$, runt-related transcription factor 3 the identification of novel treatment strategies for this disease. Therefore, the development of more effective and low-toxicity chemotherapeutic agents is urgently required.

Paeonol (2-hydroxy-4-methoxyacetophenone), a major active extract from the root bark of Paeonia suffruticosa Andrews (2), possesses a number of biological activities, including anti-inflammatory $(3,4)$, antioxidant $(5)$, anti-angiogenic (6), anti-allergic (7) and anti-oxidation (8). Previous studies have revealed that paeonol exhibits antiproliferative effects and apoptosis-inducing activities in various tumor cell lines in vitro and in vivo (9-13). Our previous study demonstrated that paeonol exhibited antineoplastic activity by promoting apoptosis in the human colorectal carcinoma cell line, HT-29 (14). However, the underlying mechanisms remain unknown. Therefore, in the present study, the effects of paeonol on cell viability, intracellular calcium concentration and the expression of runt-related transcription factor 3 (RUNX3) were investigated in LoVo human colorectal cancer cells and the antitumor mechanisms of paeonol were analyzed.

\section{Materials and methods}

Materials. Human colon cancer cell line, LoVo, was obtained from the Cell Collection Center of Chinese Academy of Sciences (Shanghai, China). Paeonol was purchased from Natura Pharmaceutical Co., Ltd. (Zhejiang, China). RPMI-1640 medium, fetal bovine serum (FBS), penicillin-streptomycin, pancreatin and glutamine were purchased from Hangzhou Sijiqing Biological Engineering Materials Co., Ltd. (Zhejiang, China). TRIzol total extraction kit was purchased from Invitrogen Life Technologies (Carlsbad, CA, USA) and the Annexin V-FITC/PI Apoptosis kit was purchased from Roche Ltd. (Shanghai, China). Fluo-3/AM was obtained from Beyotime Institute of Biotechnology (Suzhou, China), diluted to a suitable concentration using DMSO, then separately loaded and stored in the dark. All other chemicals were of reagent grade and obtained from commercial sources. The study was approved by the ethics committee of Renmin Hospital of Wuhan University, Wuhan, China.

Cell culture. Cells were incubated in RPMI-1640 medium supplemented with $10 \%$ FBS, $2 \mathrm{mM}$ L-glutamine and $1 \%$ penicillin-streptomycin at $37^{\circ} \mathrm{C}$ in the presence of $5 \%$ $\mathrm{CO}_{2}$; transfer of culture was performed once every 3-4 days. When the cells reached logarithmic growth, $0.25 \%$ pancreatin 
was used to treat the cells for $2 \mathrm{~min}$. The digested cells were resuspended using RPMI-1640 medium containing 10\% FBS and counted, and the concentration of cells was adjusted to $1 \times 10^{4}$ cells $/ \mathrm{ml}$.

Cell proliferation assay. To evaluate the effect of paeonol on the proliferation and viability of LoVo cells, cells were seeded at a density of $5 \times 10^{3}$ cells/well containing $100 \mu 1$ culture medium in 96-well plates. Following $24 \mathrm{~h}$ cultivation, the medium was replaced with fresh medium supplemented with various concentrations of paeonol and further cultivated for the indicated periods. Paeonol was added to the culture medium at a final concentration of $15.63-250 \mathrm{mg} / \mathrm{l}$. The control culture received only the culture medium. Following further incubation, $10 \mu \mathrm{l}$ WST- 8 reagent was added to each well of a $96-w e l l$ plate, followed by incubation for $3 \mathrm{~h}$ at $37^{\circ} \mathrm{C}$. The number of viable cells was determined using the absorbance at $450 \mathrm{~nm}$. The wells without paeonol and the free cells (culture medium alone) were used as blanks. Data are expressed as percentages of the controls.

Cell cycle analysis. Cell cycle status was determined by measuring cellular DNA content following staining with propidium iodide using flow cytometry. After treatment, the LoVo cells were centrifuged, washed twice with ice-cold phosphate-buffered saline (PBS) and fixed in 70\% ethanol at $4^{\circ} \mathrm{C}$ for $24 \mathrm{~h}$. Cells were then centrifuged at $1,200 \mathrm{x}$ g for $5 \mathrm{~min}$ and the supernatant was discarded. Pellets were washed twice with $4 \mathrm{ml}$ PBS and stained with $0.5 \mathrm{ml}$ RNase A $(2 \mathrm{mg} / \mathrm{ml})$ and $0.5 \mathrm{ml}$ propidium iodide ( $0.1 \%$ in $0.6 \%$ Triton-X in PBS) for $30 \mathrm{~min}$ in the dark. The samples were then analyzed on a FACSCalibur flow cytometer (Beckman Coulter, Inc., Fullerton, CA, USA).

Cell apoptosis assay. To quantify apoptosis, cells were stained with Annexin V and PI using the Annexin V-FITC/PI Apoptosis kit according to the manufacturer's instructions. Briefly, the cells were washed twice with cold PBS following treatment and resuspended in $195 \mu \mathrm{l}$ Annexin V-FITC binding buffer. Annexin V-FITC (5 $\mu \mathrm{l})$ was added and mixed gently and the cells were incubated for $15 \mathrm{~min}$ at room temperature in the dark. The cells were then centrifuged at $1,000 \mathrm{x} \mathrm{g}$ for 5 min and gently resuspended in $190 \mu 1$ Annexin V-FITC binding buffer. Following this, $10 \mu \mathrm{l}$ propidium iodide staining solution was added and gently mixed. The cells were kept on ice in the dark and immediately subjected to flow cytometry. FCM Cell Quest software was used to analyze the data.

Intracellular $\mathrm{Ca}^{2+}$ assay. After $48 \mathrm{~h}$, LoVo cells treated with or without paeonol were removed from the incubator. Culture solution in the $35-\mathrm{mm}$ dishes was removed, the cells were rinsed 3 times with HEPES and $4 \mu \mathrm{g} / \mathrm{ml}$ Fluo-3/AM (Beyotime Institute of Biotechnology) was added (200 $\mu \mathrm{l} / \mathrm{dish})$. Next, the cells were incubated at $37^{\circ} \mathrm{C}$ for $60 \mathrm{~min}$, followed by 3 washes with HEPES to discard the remaining extracellular probe and $200 \mu$ l HEPES culture medium was used to cover all cells in the troughs. Laser scanning confocal microscopy (LSCM) was performed to observe the fluorescence intensity (FI) of the cells, using an excitation wavelength of $488 \mathrm{~nm}$ and emission wavelength of $555 \pm 15 \mathrm{~nm}$.

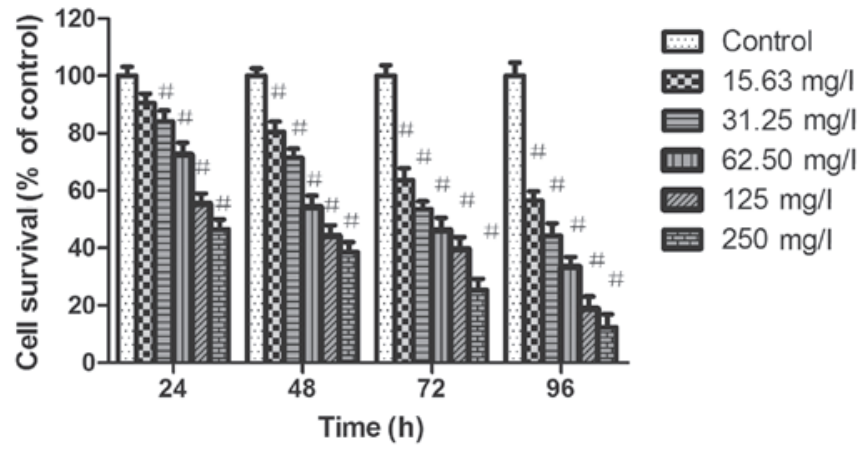

Figure 1. Paeonol inhibits the proliferation of LoVo cells in vitro. LoVo cells were treated with increasing concentrations of paeonol for the indicated times and cell proliferation was measured using the WST- 8 assay. The number of viable cells was proportional to the absorbance. Treatment with paeonol caused the dose- and time-dependent inhibition of cell proliferation. ${ }^{\#} \mathrm{P}<0.05$ vs. untreated controls.

$R N A$ preparation and reverse transcription polymerase chain reaction ( $R T-P C R)$. Total RNA was isolated using TRIzol reagent and $1 \mu \mathrm{g}$ RNA was used as a template for the synthesis of cDNA using the RevertAid First Strand cDNA Synthesis kit (Fermentas, Waltham, MA, USA) according to the manufacturer's instructions. PCR analysis was performed in a final volume of $25 \mu \mathrm{l}$ using PCR Master Mix (Fermentas). Primer sequences were designed using Primer Premier 3 (Applied Biosystems, Carlsbad, CA, USA) and were as follows: RUNX3, forward 5'-CAGAAGCTGGAGGACCAGAC-3' and reverse 5'-TCGGAGAATGGGTTCAGTTC-3'; and $\beta$-actin, forward 5'-CACGATGGAGGGGCCGGACTCATC-3' and reverse 5'-TAAAGACCTCTATGCCAACACAGT-3'. PCR products were separated in $1.5 \%$ agarose gel, stained with ethidium bromide and images were captured.

Statistical analysis. All continuous values are expressed as the mean \pm SD. Student's t-test was used for comparison of the values between two groups. SPSS 16.0 (SPSS Inc., Chicago, IL, USA) was used for statistical analysis. $\mathrm{P}<0.05$ was considered to indicate a statistically significant difference.

\section{Results}

Effect of paeonol on proliferation in human colon cancer LoVo cells. To determine the potential effect on cell growth, LoVo cells were treated with increasing concentrations of paeonol for various durations. The growth inhibition of LoVo cells was determined using the WST- 8 assay. The amount of yellow formazan dye generated by dehydrogenase activity in the cells was directly proportional to the number of living cells in the culture medium. As demonstrated in Fig. 1, paeonol significantly inhibited the proliferation of LoVo cells. The viability of LoVo cells treated with paeonol decreased in a dose- and time-dependent manner between 24 and $96 \mathrm{~h}$ incubation.

Effect of paeonol on the cell cycle in human colon cancer LoVo cells. The $\mathrm{G}_{1} / \mathrm{S}$ transition is one of the two main checkpoints that regulate cell cycle progression and thus cell proliferation. In the present study, the effect of paeonol on the 

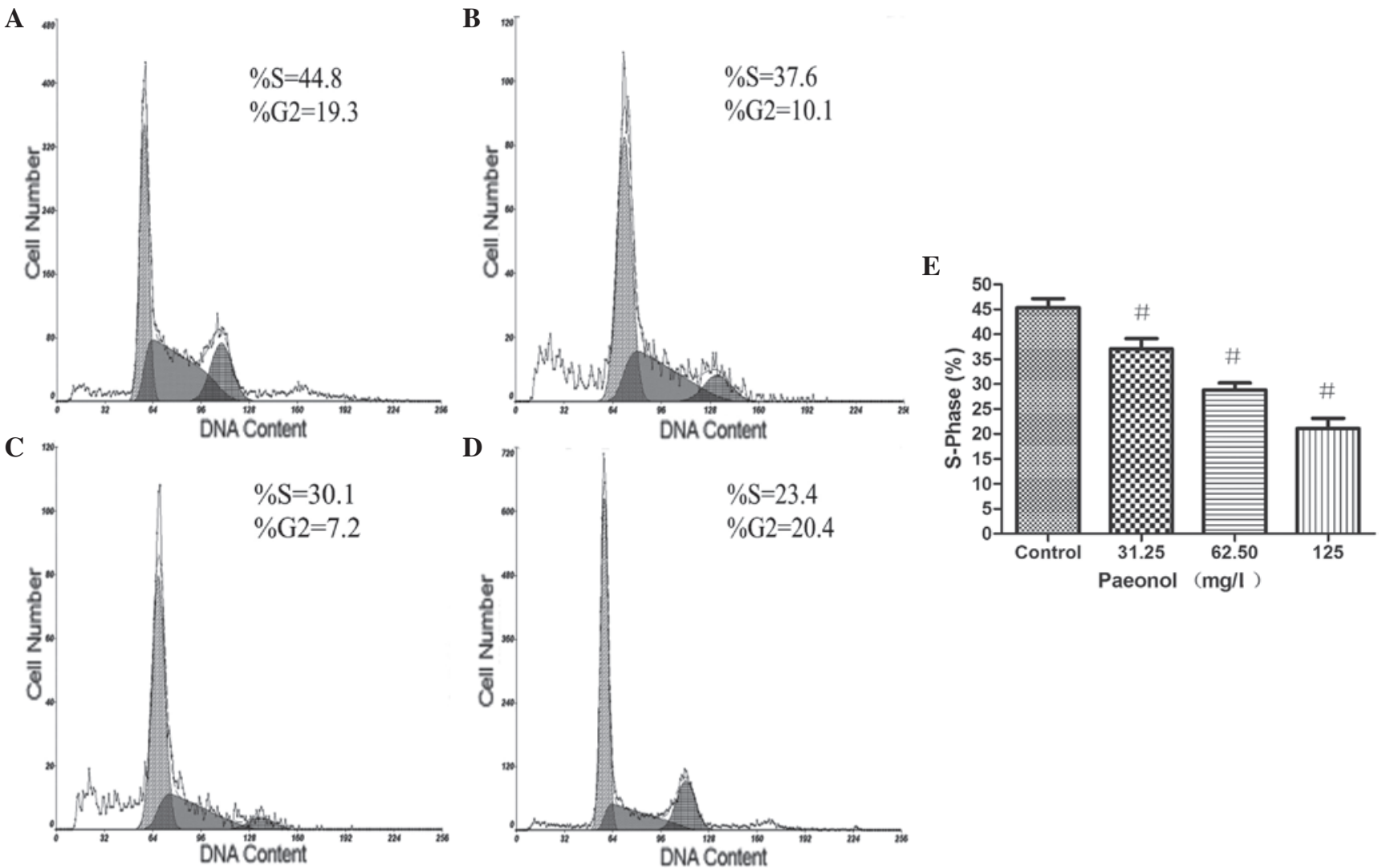

Figure 2. Paeonol blocked the cell cycle at the $\mathrm{G}_{1}$ to $\mathrm{S}$ transition in LoVo cells. Cells were treated with the indicated concentrations of paeonol for $48 \mathrm{~h}$, stained with PI and analyzed by flow cytometry. (A) Control; and paeonol at (B) 31.25, (C) 62.50 and (D) $125 \mathrm{mg} / 1$. Images are representative of three independent experiments. (E) The proportion of DNA in the S phase was calculated using flow cytometry software. Paeonol markedly decreased the percentage of S-phase cells. ${ }^{"} \mathrm{P}<0.05$ vs. control cells.
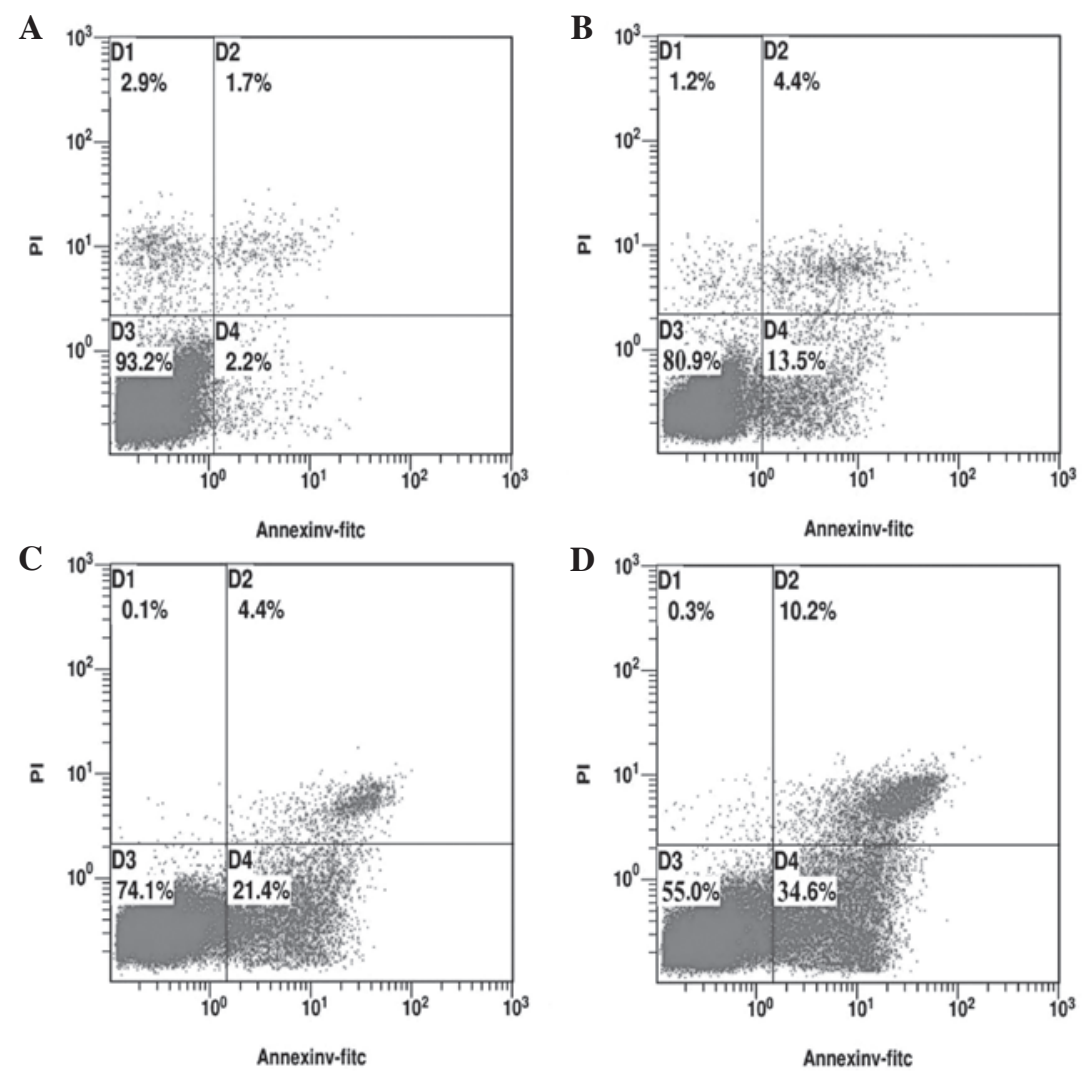

Figure 3. Paeonol induced apoptosis in LoVo cells. LoVo cells were treated with the indicated concentrations of paeonol for $48 \mathrm{~h}$ and the effect of paeonol on cell apoptosis was analyzed by flow cytometry. (A) Control; and paeonol at (B) 31.25 , (C) 62.50 and (D) $125 \mathrm{mg} / 1$. 

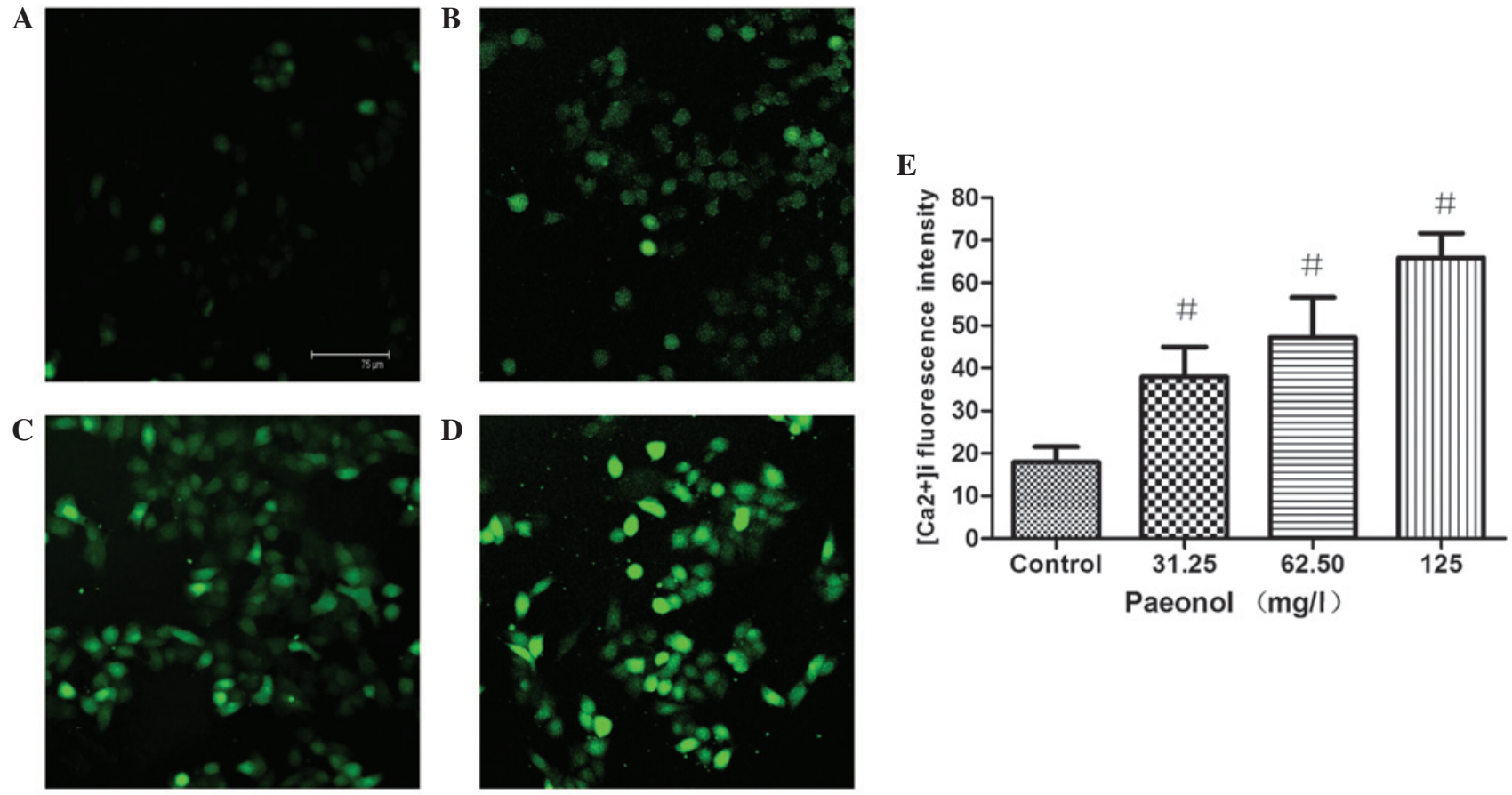

Figure 4. Intracellular calcium accumulation occurred in paeonol-treated LoVo cells. Images (green) reveal $\left[\mathrm{Ca}^{2+}\right]_{\mathrm{i}}$ captured under a confocal microscope, with the depth of the color representing the fluorescence intensity (FI), which indirectly reflects $\left[\mathrm{Ca}^{2+}\right]_{\mathrm{i}}$. (A) Control; and paeonol at (B) 31.25 , (C) 62.50 and (D) $125 \mathrm{mg} / \mathrm{l}$. (E) Quantification of FI obtained through LSCM for the various groups. ${ }^{~} \mathrm{P}<0.05$ vs. control group. $\left[\mathrm{Ca}^{2+}\right]_{\mathrm{i}}$, intracellular free $\mathrm{Ca}^{2+}$ concentration; LSCM, laser scanning confocal microscopy.
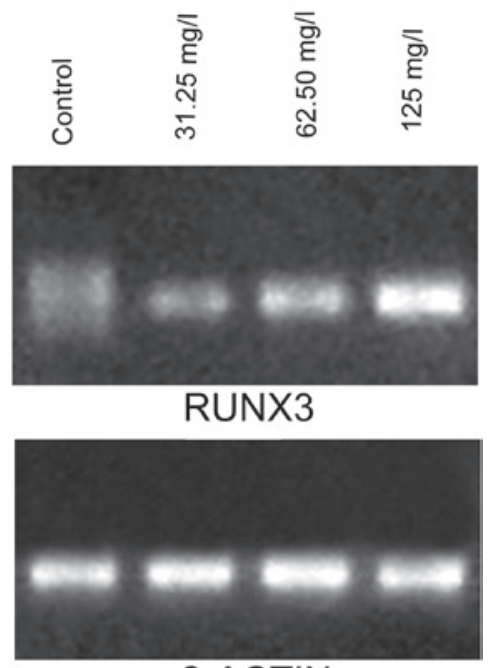

$\beta-A C T I N$

Figure 5. Paeonol promoted the expression of RUNX3 in LoVo cells. Following exposure to various concentrations for $48 \mathrm{~h}, \mathrm{LoV}$ o cells were observed to have a dose-dependent increase in RUNX3. $\beta$-actin functioned as an internal control. RUNX3, runt-related transcription factor 3.

$\mathrm{G}_{1}$ to $\mathrm{S}$ transition in LoVo cells was investigated via PI staining followed by FACS analysis. As demonstrated in Fig. 2A and B, the percentage of S-phase cells following treatment with 0 , $31.25,62.5$ and $125 \mathrm{mg} / \mathrm{l}$ paeonol was $45.37 \pm 2.9,37.07 \pm 3.2$, $28.87 \pm 2.4$ and $21.10 \pm 3.4 \%$, respectively $(\mathrm{P}<0.05)$, indicating that paeonol inhibits LoVo cell proliferation by blocking the cell cycle at the $\mathrm{G}_{1}$ to $\mathrm{S}$ transition.
Effect of paeonol on cell apoptosis in human colon cancer LoVo cells. Flow cytometry analysis was performed to analyze apoptosis in LoVo cells treated with various concentrations of paeonol for $48 \mathrm{~h}$. As revealed in Fig. 3, the proportion of apoptotic cells increased from $12.4 \pm 2.1$ to $35.1 \pm 3.7 \%$ in a dose-dependent manner. The percentage of apoptotic cells treated with paeonol was significantly higher compared with that in the control group $(\mathrm{P}<0.01)$, indicating that paeonol may inhibit the growth of cultured LoVo cells by inducing apoptosis.

Effect of paeonol on intracellular free $\mathrm{Ca}^{2+}$ concentration $\left(\left[\mathrm{Ca}^{2+}\right]_{i}\right)$ in human colon cancer LoVo cells. To explore whether paeonol-induced apoptosis is associated with $\left[\mathrm{Ca}^{2+}\right]_{\mathrm{i}}$, the effect of various concentrations of paeonol on $\left[\mathrm{Ca}^{2+}\right]_{\mathrm{i}}$ in $\mathrm{LoVo}$ cells was observed using LSCM after staining with the fluorescent probe, Fluo-3/AM. As demonstrated in Fig. 4, images reveal $\left[\mathrm{Ca}^{2+}\right]_{\mathrm{i}}$ captured under a confocal microscope, with the depth of the green color representing the FI, which indirectly reflects $\left[\mathrm{Ca}^{2+}\right]_{\mathrm{i}}$. Control $\left[\mathrm{Ca}^{2+}\right]_{\mathrm{i}}$ was revealed to be extremely low, while $\left[\mathrm{Ca}^{2+}\right]_{\mathrm{i}}$ in all the paeonol-treated groups (Fig. 4A-D) was increased after $48 \mathrm{~h}$, in a concentration-dependent manner. FI values, obtained by LCSM, were consistent with these observations $(\mathrm{P}<0.05$; Fig. 4E). These results indicate that paeonol induces a dose-dependent $\left[\mathrm{Ca}^{2+}\right]_{\mathrm{i}}$ influx and may induce the apoptosis or necrosis that follows via calcium ion overload.

Effect of paeonol on expression of RUNX3 in human colon cancer LoVo cells. RUNX3 is known to play a tumor suppressive role in various types of cancer. In particular, RUNX3 appears to be an important component of the transforming growth factor- $\beta$ (TGF- $\beta$ )-induced tumor suppression pathway. 
To elucidate the interaction between RUNX3 and paeonol, LoVo cells were exposed to $0,31.25,62.5$ or $125 \mathrm{mg} / \mathrm{l}$ paeonol for $48 \mathrm{~h}$ and the expression of RUNX3 was detected, as demonstrated in Fig. 5. RUNX3 mRNA levels in cells treated with $31.25 \mathrm{mg} / 1$ paeonol were observed to be higher than those in the controls. Treatment with $125 \mathrm{mg} / \mathrm{l}$ paeonol led to a further increase, indicative of a dose-dependent increase in RUNX3 expression.

\section{Discussion}

Apoptosis is a physiological process that controls cell numbers and proliferation in order to maintain homeostasis in multi-cellular organisms $(15,16)$. The balance between cell proliferation and apoptosis and cell cycle distribution are extremely important factors during the process of carcinogenesis in colon cancer (17). Apoptosis, a highly regulated death process by which cells undergo inducible non-necrotic cellular suicide, is vital for anti-carcinogenesis (18). Therefore, agents that facilitate apoptosis are likely to improve therapeutic efficacy. In the present study, paeonol was observed to inhibit the proliferation of LoVo cells in a dose- and time-dependent manner (Fig. 1) and consistent results have been observed in other cancer cell lines (data not shown). Analysis of long-term cell viability also revealed that cytotoxicity levels were altered in a dose-dependent manner. Results from flow cytometry revealed that paeonol markedly decreased the percentage of S-phase cells, indicating that paeonol may suppress cell growth by blocking the cell cycle at the $G_{1}$ to $S$ transition, which promotes apoptosis. To test this hypothesis, Annexin V/PI staining was performed and the results demonstrated that paeonol significantly induced apoptosis in LoVo cells (Fig. 3). Additionally, our previous study showed that paeonol regulated the expression of Fas, Bcl-2, Bax and p53, leading to the induction of apoptosis (14). These results indicated that paeonol may inhibit the proliferation of cultured LoVo cells by activating the apoptotic signaling pathway.

In addition, the underlying mechanisms of apoptosis induction in LoVo cells were investigated. The $\left[\mathrm{Ca}_{2+}\right]_{\mathrm{i}}$ in $\mathrm{LoVo}$ cells was observed to be significantly increased when cells were cultured with paeonol at 31.25-125 mg/l (Fig. 4). $\mathrm{Ca}^{2+}$ ions are crucial in a number of physiological and pathological processes for the majority of cell types (19). A rise in $\left[\mathrm{Ca}^{2+}\right]_{\mathrm{i}}$ is associated with various cellular functions, including proliferation, division, fertilization, movement and apoptosis (20). It has been reported that increases in cytosolic $\mathrm{Ca}^{2+}$ concentrations occur at the early and late stages of the apoptotic pathway $(21,22)$. $\mathrm{Ca}^{2+}$ overload has also been hypothesized to be the final common pathway for all types of cell death. In the present study, fluorescence microscopy revealed that the $\left[\mathrm{Ca}^{2+}\right]_{\mathrm{i}}$ FI of cells loaded with Fluo-3/AM in the control group was extremely low, while that in all the paeonol-treated groups was markedly increased in a dose-dependent manner. These results indicate that paeonol-induced increases in $\left[\mathrm{Ca}^{2+}\right]_{\mathrm{i}}$ play a pivotal role in eliciting early signals for triggering apoptosis.

Additionally, in the present study, paeonol was shown to promote the expression of RUNX3 in LoVo cells in a dose-dependent manner $(\mathrm{P}<0.05)$. RUNX3 (chromosome 1p36.1) belongs to the RUNX family of transcription factors (23) and has been reported to function as a tumor suppressor in various forms of cancer. RUNX3 is an important target of the TGF- $\beta$ signaling pathway (24) and an inhibitor of the Wnt pathway $(25,26)$. Previous studies have revealed that the central role of RUNX3 in tumor formation may be associated with its developmental significance $(27,28)$. The major reason for the lost or decreased expression of RUNX3 is hypermethylation of the RUNX3 proximal promoter $\mathrm{CpG}$ island, which is involved in the formation of a number of cancer types, including breast (29), gastric $(30,31)$ and colon cancer $(32,33)$. The restoration of RUNX3 has been revealed to result in the marked suppression of tumor growth and metastasis by inducing cell cycle arrest, apoptosis and the downregulation of cyclinD1 expression in gastric cancer cell lines $(34,35)$. In the current study, paeonol was shown to significantly upregulate the expression of RUNX3 in LoVo cells. FACS analysis indicated that paeonol blocked the cell cycle at the $G_{1}$ to $S$ transition. Flow cytometry revealed that paeonol significantly induced apoptosis in LoVo cells. These results indicate that paeonol induces apoptosis by promoting the expression of RUNX3, which blocks the cell cycle at the $\mathrm{G}_{1}$ to $\mathrm{S}$ transition and thus interferes with DNA synthesis.

In addition to increasing $\left[\mathrm{Ca}^{2+}\right]_{\mathrm{i}}$, paeonol was shown to simultaneously upregulate the expression of RUNX3, indicating that these processes may be associated with the same apoptotic pathway. It has been reported that a rise in $\left[\mathrm{Ca}^{2+}\right]_{\mathrm{i}}$ is important for various biological responses, including gene transcription and apoptosis (36). The restoration of Runx3, a tumor suppressor, may inhibit tumor growth and metastasis by the induction of cell cycle arrest and apoptosis. In the present study, $\left[\mathrm{Ca}^{2+}\right]_{\mathrm{i}}$ and the expression of RUNX3 were demonstrated to be positively correlated following paeonol treatment. Consequently, we hypothesized that $\left[\mathrm{Ca}^{2+}\right]_{\mathrm{i}}$ and RUNX3 may cooperate in inhibiting the proliferation of colorectal carcinoma cells and promoting apoptosis. More specifically, increased $\left[\mathrm{Ca}^{2+}\right]_{\mathrm{i}}$ causes apoptosis and the upregulation of RUNX3, and RUNX3 induces apoptosis and thus increases $\left[\mathrm{Ca}^{2+}\right]_{\mathrm{i}}$.

Based on results of the present study, paeonol exhibits a marked antitumor effect and one of the antitumor mechanisms of paeonol may be associated with apoptosis induction by increased $\left[\mathrm{Ca}^{2+}\right]_{i}$ and the upregulation of RUNX3 expression. Additional studies are required to investigate the apoptotic mechanism of paeonol and its suitability as a novel strategy for the therapy of colon carcinoma.

\section{Acknowledgements}

The present study was supported by grants from the Natural Science Foundation of Hubei Province (no. 2010CDB06908), Wuhan Science and Technology Bureau Fund (no. 201060938363-05) and the Fundamental Research Funds for the Central Universities (no. 201130202020017).

\section{References}

1. Strimpakos AS, Cunningham D, Mikropoulos C, Petkar I, Barbachano Y and Chau I: The impact of carcinoembryonic antigen flare in patients with advanced colorectal cancer receiving first-line chemotherapy. Ann Oncol 21: 1013-1019, 2010.

2. Riley CM and Ren TC: Simple method for the determination of paeonol in human and rabbit plasma by high-performance liquid chromatography using solid-phase extraction and ultraviolet detection. J Chromatogr 489: 432-437, 1989. 
3. Chou TC: Anti-inflammatory and analgesic effects of paeonol in carrageenan-evoked thermal hyperalgesia. Br J Pharmacol 139: $1146-1152,2003$.

4. Huang H, Chang EJ, Lee Y, Kim JS, Kang SS and Kim HH: A genome-wide microarray analysis reveals anti-inflammatory target genes of paeonol in macrophages. Inflamm Res 57: 189-198, 2008.

5. Hsieh CL, Cheng CY, Tsai TH, Lin IH, Liu CH, Chiang SY, Lin JG, Lao CJ and Tang NY: Paeonol reduced cerebral infarction involving the superoxide anion and microglia activation in ischemia-reperfusion injured rats. J Ethnopharmacol 106: 208-215, 2006.

6. Kim SA, Lee HJ, Ahn KS, Lee HJ, Lee EO, Ahn KS, Choi SH, Jung SJ, Kim JY, Baek N and Kim SH: Paeonol exerts anti-angiogenic and anti-metastatic activities through downmodulation of Akt activation and inactivation of matrix metalloproteinases. Biol Pharm Bull 32: 1142-1147, 2009.

7. Kim SH, Kim SA, Park MK, Kim SH, Park YD, Na HJ, Kim HM, Shin MK and Ahn KS: Paeonol inhibits anaphylactic reaction by regulating histamine and TNF-alpha. Int Immunopharmacol 4: 279-287, 2004.

8. Sun YC, Shen YX and Sun GP: Advances in the studies of major pharmacological activity of paeonol. Zhong Cheng Yao Zazhi 26: 579-582, 2004 (In Chinese).

9. Chen B, Ning M and Yang G: Effect of paeonol on antioxidant and immune regulatory activity in hepatocellular carcinoma rats. Molecules 17: 4672-4683, 2012.

10. Li N, Fan LL, Sun GP, Wan XA, Wang ZG, Wu Q and Wang H: Paeonol inhibits tumor growth in gastric cancer in vitro and in vivo. World J Gastroenterol 16: 4483-4490, 2010.

11. Lee HJ, Kim SA, Lee HJ, Jeong SJ, Han I, Jung JH, Lee EO, Zhu S, Chen CY and Kim SH: Paeonol oxime inhibits bFGF-induced angiogenesis and reduces VEGF levels in fibrosarcoma cells. PLoS One 5: e12358, 2010.

12. Wan XA, Sun GP, Wang H, Xu SP, Wang ZG and Liu SH: Synergistic effect of paeonol and cisplatin on oesophageal cancer cell lines. Dig Liver Dis 40: 531-539, 2008.

13. Xing G, Zhang Z, Liu J, Hu H and Suqiura N: Antitumor effect of extracts from moutan cortex on DLD-1 human colon cancer cells in vitro. Mol Med Rep 3: 57-61, 2010.

14. Ye JM, Deng T and Zhang JB: Influence of paeonol on expression of COX-2 and p27 in HT-29 cells. World J Gastroenterol 15: 4410-4414, 2009.

15. LaCasse EC, Mahoney DJ, Cheung HH, Plenchette S, Baird S and Korneluk RG: IAP-targeted therapies for cancer. Oncogene 27: 6252-6275, 2008.

16. Wang S: The promise of cancer therapeutics targeting the TNF-related apoptosis-inducing ligand and TRAIL receptor pathway. Oncogene 27: 6207-6215, 2008

17. Huang WS, Wang JP, Wang T, Fang JY, Lan P and Ma JP: ShRNA-mediated gene silencing of beta-catenin inhibits growth of human colon cancer cells. World J Gastroenterol 13: 6581-6587, 2007.

18. Kaufmann SH and Hengartner MO: Programmed cell death: alive and well in the new millennium. Trends Cell Biol 11: 526-534, 2001

19. Clapham DE: Intracellular calcium. Replenishing the stores. Nature 375: 634-635, 1995.

20. Bootman MD, Berridge MJ and Roderick HL: Calcium signalling: more messengers, more channels, more complexity. Curr Biol 12: R563-R565, 2002.

21. Kruman I, Guo Q and Mattson MP: Calcium and reactive oxygen species mediate staurosporine-induced mitochondrial dysfunction and apoptosis in PC12 cells. J Neurosci Res 51: 293-308, 1998.
22. Martikainen P, Kyprianou N, Tucker RW and Isaacs JT: Programmed death of nonproliferating androgen-independent prostatic cancer cells. Cancer Res 51: 4693-4700, 1991.

23. Bangsow C, Rubins N, Glusman G, Bernstein Y, Negreanu V, Goldenberg D, Lotem J, Ben-Asher E, Lancet D, Levanon D and Groner Y: The RUNX3 gene - sequence, structure and regulated expression. Gene 279: 221-232, 2001.

24. Subramaniam MM, Chan JY, Yeoh KG, Quek T, Ito K and Salto-Tellez M: Molecular pathology of RUNX3 in human carcinogenesis. Biochim Biophys Acta 1796: 315-331, 2009.

25. Ito K, Lim AC, Salto-Tellez M, Motoda L, Osato M, Chuang LS, Lee CW, Voon DC, Koo JK, Wang H, Fukamachi $\mathrm{H}$ and Ito Y: RUNX3 attenuates beta-catenin/T cell factors in intestinal tumorigenesis. Cancer Cell 14: 226-237, 2008.

26. Licchesi JD, Westra WH, Hooker CM, Machida EO, Baylin SB and Herman JG: Epigenetic alteration of Wnt pathway antagonists in progressive glandular neoplasia of the lung. Carcinogenesis 29: 895-904, 2008.

27. Lee JM, Kwon HJ, Bae SC and Jung HS: Lung tissue regeneration after induced injury in Runx3 KO mice. Cell Tissue Res 341: 465-470, 2010.

28. Lee KS, Lee YS, Lee JM, Ito K, Cinghu S, Kim JH, Jang JW, Li YH, Goh YM, Chi XZ, Wee H, Lee HW, Hosoya A, Chung JH, Jang JJ, Kundu JK, Surh YJ, Kim WJ, Ito Y, Jung HS and Bae SC: Runx3 is required for the differentiation of lung epithelial cells and suppression of lung cancer. Oncogene 29: 3349-3361, 2010.

29. Subramaniam MM, Chan JY, Soong R, Ito K, Ito Y, Yeoh KG, Salto-Tellez M and Putti TC: RUNX3 inactivation by frequent promoter hypermethylation and protein mislocalization constitute an early event in breast cancer progression. Breast Cancer Res Treat 113: 113-121, 2009.

30. Ito K, Liu Q, Salto-Tellez M, Yano T, Tada K, Ida H, Huang C, Shah N, Inoue M, Rajnakova A, Hiong KC, Peh BK, Han HC, Ito T, Teh M, Yeoh KG and Ito Y: RUNX 3, a novel tumor suppressor, is frequently inactivated in gastric cancer by protein mislocalization. Cancer Res 65: 7743-7750, 2005.

31. Li QL, Ito K, Sakakura C, Fukamachi H, Inoue KI, Chi XZ, Lee KY, Nomura S, Lee CW, Han SB, Kim HM, Kim WJ, Yamamoto H, Yamashita N, Yano T, Ikeda T, Itohara S, Inazawa J, Abe T, Hagiwara A, Yamagishi H, Ooe A, Kaneda A, Sugimura T, Ushijima T, Bae SC and Ito Y: Causal relationship between the loss of RUNX3 expression and gastric cancer. Cell 109: 113-124, 2002.

32. Ahlquist T, Lind GE, Costa VL, Meling GI, Vatn M, Hoff GS, Rognum TO, Skotheim RI, Thiis-Evensen E and Lothe RA: Gene methylation profiles of normal mucosa and benign and malignant colorectal tumors identify early onset markers. Mol Cancer 7: 94, 2008.

33. Subramaniam MM, Chan JY, Soong R, Ito K, Yeoh KG, Wong R, Guenther T, Will O, Chen CL, Kumarasinghe MP, Ito Y and Salto-Tellez M: RUNX3 inactivation in colorectal polyps arising through different pathways of colonic carcinogenesis. Am J Gastroenterol 104: 426-436, 2009.

34. Chi XZ, Yang JO, Lee KY, Ito K, Sakakura C, Li QL, Kim HR, Cha EJ, Kaneda A, Ushijima T, Kim WJ, Ito Y and Bae SC: RUNX3 suppresses gastric epithelial cell growth by inducing $\mathrm{p} 21^{\mathrm{WAF} 1 / \mathrm{Cipl}}$ expression in cooperation with transforming growth factor $\beta$-activated SMAD. Mol Cell Biol 25: 8097-8107, 2005.

35. Wei D, Gong W, Oh SC, Li Q, Kim WD, Wang L, Le X, Yao J, Wu TT, Huang S and Xie K: Loss of RUNX3 expression significantly affects the clinical outcome of gastric cancer patients and its restoration causes drastic suppression of tumor growth and metastasis. Cancer Res 65: 4809-4816, 2005.

36. Müller I,Lipp P and Thiel G: $\mathrm{Ca}^{2+}$ signaling and gene transcription in glucose-stimulated insulinoma cells. Cell Calcium 52: 137-151, 2012 . 